\title{
Tracking hantavirus nucleocapsid protein using intracellular antibodies
}

\author{
Jiandong Li ${ }^{2 \dagger}$, Quanfu Zhang ${ }^{1 \dagger}$, Tao Wang ${ }^{1}$, Chuan Li', Mifang Liang ${ }^{1 *}$, Dexin $\mathrm{Li}^{2}$
}

\begin{abstract}
Background: Hantavirus nucleocapsid (N) protein is a multifunctional viral macromolecule involved in multiple stages of the viral replication cycle. The intracellular trafficking of $N$ protein during virus assembly remains unclear.

Methods: We used N protein-specific intracellular expressed antibodies to track the localization and distribution of Hantaan virus and Seoul virus N protein. The N protein-specific antibody single-chain variable antibody fragments (scFvs), which bind an N-terminal linear epitope (L13F3) and C-terminal conformational domain (H34), were intracellularly expressed in the endoplasmic reticulum (ER) by fusion of the SEKDEL retention signal peptide at the carboxyl terminus, and in the cytoplasm (Cyto) by deletion of the ER membrane target signal peptide. Stable VeroE6 cell lines expressing intracellular scFvs were either infected with hantavirus or transfected with an $\mathrm{N}$ protein expression plasmid; virus replication and $\mathrm{N}$ protein intracellular localization were determined.
\end{abstract}

Result: N protein co-localized with scFvs in the ER and cytoplasm with or without viral membrane glycoproteins. Hantavirus replication was inhibited in both the scFvs-ER- and scFvs-Cyto-expressing stable cell lines.

Conclusion: $N$ protein may be expressed in the ER retention signal peptide of KDEL circulating region (ER/cisGolgi) without the assistance of $\mathrm{G}$ protein, and so expression of $\mathrm{N}$ protein in both the cytoplasm and within the ER/cis-Golgi plays an important role in virus replication.

\section{Background}

Hantaviruses are members of the Bunyaviridae family, which contain three negative-sense, single-stranded RNA genome segments designated large (L), medium $(\mathrm{M})$, and small $(\mathrm{S})$ [1]. The $\mathrm{S}, \mathrm{M}$, and $\mathrm{L}$ segments encode the nucleocapsid protein $(\mathrm{N})$, glycoproteins $(\mathrm{Gn}$ and Gc), and L protein (an RNA-dependent RNA polymerase), respectively. Hantaviruses do not have matrix proteins, but the $\mathrm{N}$ protein has been proposed to play a key role in virus assembly [2]. $\mathrm{N}$ protein is expressed in the cytoplasm, viral glycoproteins are co-translated in the endoplasmic reticulum (ER), once cleaved, Gn and Gc undergo glycosylation, folding, and heterodimerization in the Golgi complex, where they are retained and accumulate. For assembly to occur, $\mathrm{N}$ as well as $\mathrm{Gn}$ and Gc, must move to the same intracellular location. After

\footnotetext{
* Correspondence: mifangl@vip.sina.com

+ Contributed equally

'State Key Laboratory for Infectious Disease Control and Prevention, Institute for Viral Disease Control and Prevention, China CDC, 155 Changbai Road,

Changping District, Beijing 102206, PR China

Full list of author information is available at the end of the article
}

interaction of $\mathrm{N}$ protein with viral RNA and subsequent assembly, ribonucleoprotein (RNP) is targeted to the Golgi complex by specific recognition of the cytoplasmic tail of Gn and Gc protein [3], the interaction of Gn protein cytoplasmic tail and the middle domain of the $\mathrm{N}$ protein was suggested to play essential role to direct RNPs to the site of the virus assembly [4] and the complete hetero-oligomeric (Gn-Gc) spike complex of hantaviruses might mediates the packaging of RNP into virions [5].

$\mathrm{N}$ protein has an intrinsic RNA chaperone activity, which is important for encapsidation and genome replication [6,7]. The RNA-binding domain of $\mathrm{N}$ protein is situated within a central conserved region between residues 175 and 217 [8]. The 141 residues proximal to the C-terminal are required for Golgi localization [9]. Both $\mathrm{N}$ - and $\mathrm{C}$-terminal regions have been implicated in homotypic $\mathrm{N}$ protein interaction, and putative coiledcoil motifs in the $\mathrm{N}$-terminal region of $\mathrm{N}$ protein have been proposed to facilitate trimerization [10-12]. $\mathrm{N}$ was not observed in the Golgi so far, but it could be observed to surround the Golgi after infection [13,9]
C Biomed Central

(c) 2010 Li et al; licensee BioMed Central Ltd. This is an Open Access article distributed under the terms of the Creative Commons Attribution License (http://creativecommons.org/licenses/by/2.0), which permits unrestricted use, distribution, and reproduction in any medium, provided the original work is properly cited. 
and it was shown that targeting of $\mathrm{N}$ protein to the ER/ Golgi intermediate compartment (ERGIC), prior to its movement to the Golgi compartment, and an intact ERGIC are necessary for viral replication [14]. However, the impact of $\mathrm{N}$ protein intracellular trafficking on the cell and its effect on virus replication remain unclear. We used intracellular expression of anti-Hantaan virus (HTNV) and Seoul virus (SEOV) N protein N-terminaland C-terminal-specific antibodies, respectively, to block or knock down $\mathrm{N}$ protein function at targeted sites, with or without co-expressed membrane glycoproteins, and assess the effect on virus replication and $\mathrm{N}$ protein intracellular trafficking. Our data showed that $\mathrm{N}$ protein co-localized with both cytoplasm and ER-retarded antibodies either with or without the help of G protein and virus replication was inhibited by related intracellular antibodies. These data suggest, therefore, that presentation of $\mathrm{N}$ protein both in the cytoplasm and within the ER/cis-Golgi plays an important role in hantavirus replication.

\section{Materials and methods}

\subsection{Cells and antibodies}

Vero-E6 cells, COS-7 cells, and a mouse hybridoma cell line L13F3 expressing mouse $\mathrm{mAb}$ binding to $\mathrm{N}$ protein of HTNV and SEOV (which targeted at a N-terminus epitope [15]) were cultured in Dulbecco's modified Eagle's medium (DMEM) supplemented with fetal calf serum (FCS; $10 \% \mathrm{v} / \mathrm{v})$, penicillin $(100 \mathrm{IU} / \mathrm{ml})$, streptomycin $(100 \mu \mathrm{g} / \mathrm{ml})$, and L-glutamine complete $(4.5 \mathrm{mM})$. The phage display-derived human $\mathrm{F}_{\mathrm{ab}} \mathrm{H} 34$, which recognizes the HTNV N protein C-terminus conformational domain, was produced in our laboratory [16].

\subsection{Plasmids}

To construct single-chain fragment variable antibody fragments (ScFvs) specific for hantaviruses $\mathrm{N}$ protein, mRNA was isolated from $\sim 1 \times 10^{6}$ L13F3 hybridoma cells using Trizol reagent (Invitrogen, Carlsbad, CA, USA). The first cDNA strand was synthesized using SuperScript ${ }^{\text {tw }}$ reverse transcriptase (Invitrogen) according to the manufacturer's directions. L13F3 heavy chain $(\mathrm{VH})$ variable region gene fragments were amplified using the forward primer 5'-GAATAGGCCATGGCGGAGGTCCAGCTGCAGGAGTCTGGGGGAGGCTTA G-3' and the reverse primer 5'-GGCCAGTGGATAAAGCTTTGGGGGTGTCGTTTTGGC-3'. NcoI and HindIII restriction sites were introduced at the 5 '- and 3'-ends, respectively, of the $\mathrm{VH}$ gene using synthetic oligonucleotides. The L13F3 V $\kappa$ gene was PCR-amplified using a forward primer with the nucleotide sequence 5'TACAGGATCCACGCGTAGACATTGTGATGACCCAGTCT-3' and a reverse primer of sequence 5'-TGACAAGCTTGCGGCCGCGGATACAGTTGGTGCAGC-
ATC-3', containing MluI and NotI sites, respectively. PCR products were subsequently inserted into plasmid pOPE-101-215 [17] between the restriction sites. The resulting plasmid was named pOPE-L13F3-scFv. As above, the H34-scFv-expressing plasmid pOPE-H34-scFv was constructed as follows: the $\mathrm{H} 34 \mathrm{VH}$ gene was amplified from the H34 $\mathrm{F}_{\mathrm{ab}}$ fragment using synthetic oligonucleotides with sequences 5'-GAATAGGCCATGGCGGAGGTGCAGCTGGAGTCT-3' and 5'-CAGTCAAGCTTTGATGAGACGGATACC-3', and NcoI and HindIII restriction sites were introduced at the 5'- and 3'-termini, respectively. The $\mathrm{H} 34 \mathrm{~V}_{\mathrm{K}}$ gene was amplified using a forward primer with the nucleotide sequence 5'TACAGGATCCACGCGTAGAAATTGTGTTGACGCAGTCTCCA-3' and the reverse primer 5'-TGACAAGCTTGCGGCCGCGAAGACAGATGGTGCAGCCACAGTTCGTCTG A-3', and MluI and NotI restriction sites were introduced at the 5'- and 3'-ends, respectively. PCR products were cloned into the plasmid pOPE-101-215.

To construct plasmids expressing intracellular scFvs in mammalian cells, the scFv gene (encoding a 6-histidine tag at the 3'-terminus) was PCR-amplified using the forward primers scFv-L13F3F-BssHII 5'-GGCGCGCACTCCGAGGTCCAGCTGCAGGAGTCTG-3', scFvH34F-BssHII 5'-GGCGCGCACTCCGAGGTGCAGCTGGAGTCT-3' and the reverse primer scFv-R-XhoI 5'CTCGAGATGATGATGGTGATGATGGGATAG-3' from plasmids pOPE-L13F3-scFv and pOPE-H34-scFv, respectively. Amplified fragments were cloned into $\mathrm{pEF} /$ myc/ER (Invitrogen) between the BssHII and XhoI restriction sites, producing the intracellular antibody expressing plasmids L13F3-scFv-ER and H34-scFv-ER. For the construction of plasmids L13F3-scFv-CYTO and $\mathrm{H} 34$-scFv-CYTO expressing cytoplasmic scFv, the scFv gene was prepared using NcoI/NotI from plasmids pOPE-L13F3-scFv and pOPE-H34-scFv and inserted into the $\mathrm{pEF} / \mathrm{myc} / \mathrm{cyto}$ vector (Invitrogen) between the $\mathrm{NcoI}$ and NotI restriction sites.

Plasmid pEF-N76118 was generated by amplifying the HTNV strain 76-118 N protein coding sequence using primers carrying adapters, and then cloned into $\mathrm{pEF} /$ myc/cyto and digestion with $\mathrm{NcoI}$ and $\mathrm{XbaI}$.

\subsection{Transfection}

The HTNV 76-118 N protein mammalian expression plasmid pEF-N76118 and intracellular antibody-expressing plasmids L13F3-scFv-ER, H34-scFv-ER, L13F3scFv-CYTO, and H34-scFv-CYTO were transiently or stably transfected into eukaryotic cells. Plasmid DNA (3 $\mu \mathrm{g}$ or $1 \mu \mathrm{g}$ ) was coated onto the bottom of each well of a 6- or 24-well plate, respectively, using Lipofectamine 2000 (Invitrogen) according to the manufacturer's instructions. COS-7 cells were co-transfected with pEF- 
N76118 and one of the antibody-expressing plasmids. Cells were harvested $48 \mathrm{~h}$ after transfection. To generate cell lines for stable expression of antibodies, Vero E6 cells were transfected with scFv-expressing plasmids; cultures supplemented with G418 $(500 \mu \mathrm{g} / \mathrm{ml})$ were started $48 \mathrm{~h}$ after transfection. Mock-transfected cells died within 7 days in selective medium. Clones were isolated using the limited dilution method, dispensed into 96-well plates, and kept under selection pressure (G418; $500 \mu \mathrm{g} / \mathrm{ml}$ ) for 14 days before reverting to normal culture medium. In this way, the antibody-expressing, stable Vero-E6 cell lines L13F3-scFv-ER-E6, H34-scFvER-E6, L13F3-scFv-CYTO-E6, and H34-scFv-CYTO-E6 were obtained.

\subsection{Immunoblot assay}

Immunoblots were used to confirm specificity of the recombinant scFvs. Routinely concentrated HTNV strain 76-118 and SEOV strain L99 prepared from Vero E6 cells $(8 \mu \mathrm{l})$ were mixed with $5 \times$ SDS-PAGE Laemmli sample buffer [ $2 \mu \mathrm{l} ; 60 \mathrm{mM}$ Tris- $\mathrm{HCl}(\mathrm{pH} 6.8), 2 \%(\mathrm{w} / \mathrm{v})$ SDS, $10 \%(\mathrm{v} / \mathrm{v})$ glycerol, $5 \%(\mathrm{v} / \mathrm{v}) \beta$-mercaptoethanol, and $0.01 \%(\mathrm{w} / \mathrm{v})$ bromophenol blue]. Following denaturing at $95^{\circ} \mathrm{C}$ for $10 \mathrm{~min}$, proteins were resolved on $12 \%$ $(\mathrm{w} / \mathrm{v})$ SDS-PAGE gels and electroblotted onto PVDF membranes. These membranes were rinsed with phosphate-buffered saline (PBS), blocked using 5\% (w/v) skim milk powder in PBS (PBS-M) for $30 \mathrm{~min}$, and probed with recombinant L13F3-scFv and H34-scFv (10 $\mathrm{ml} ; 1 \mu \mathrm{g} / \mathrm{ml}$ ) from XL1-Blue in PBS-M at room temperature (RT) for $2 \mathrm{~h}$. After washing, the membrane was incubated in mouse anti-penta-His monoclonal antibody (1:1000 in PBS-M) for $1 \mathrm{~h}$ at RT. Membranes were then washed and incubated with goat anti-mouse IgG gamma chain-specific AP-conjugated antibody (1:1000 dilution in PBS-M) (Sigma) for $1 \mathrm{~h}$ at RT. After washing, membranes were developed in BCIP/NBT (Roth, Karlsruhe, Germany) substrate solution. All washes were performed thrice for $5 \mathrm{~min}$ each in $0.05 \%(\mathrm{v} / \mathrm{v})$ PBS-T.

\subsection{Enzyme-linked immunosorbent assay (ELISA)}

To determine the concentration of viral particles in culture supernatants, group-specific L13F3 mouse anti-N $\mathrm{mAb}$ was coated onto 96-well microtiter plates overnight at $4^{\circ} \mathrm{C}$. Coated plates were blocked with $5 \%(\mathrm{w} / \mathrm{v})$ skimmed milk in PBS, and serial dilutions of detergenttreated culture supernatants were added. After washing, bound viral particles were detected by horseradish peroxidase-conjugated L13F3 mAb diluted 1:1000 in PBST. After washing three times with PBS-T, TMB peroxidase substrate $[100 \mu \mathrm{l}$; dimethylformamide and hydrogen peroxide $\left(\mathrm{H}_{2} \mathrm{O}_{2}\right)$ ] was added and developed at RT for $\sim 30 \mathrm{~min}$. The reaction was stopped by adding $\mathrm{H}_{2} \mathrm{SO}_{4}(100 \mu \mathrm{l} ; 1 \mathrm{~N}) . \mathrm{A}_{450}$ (reference $620 \mathrm{~nm}$ ) was read using a DTX 880 multi-mode detector (Beckman Coulter, Fullerton, CA, USA). The cutoff value was three standard deviations above the mean absorbance of the negative control wells.

\subsection{Virus infection}

HTNV strain 76-118 and SEOV strain L99 were propagated on Vero E6 cells. Cell cultures were harvested at 10 days postinfection; cell debris was removed by centrifugation at $4000 \times g$ and samples stored in 1-ml aliquots at $-80^{\circ} \mathrm{C}$. Vero $\mathrm{E} 6$ cells and the intracellular antibodyexpressing Vero-E6 cell lines L13F3-scFv-ER-E6, H34scFv-ER-E6, L13F3-scFv-CYTO-E6, and H34-scFvCYTO-E6 were cultured in T25 flasks to $85 \%$ confluence; cells were washed twice with pre-warmed serumfree DMEM and virus 76-118 and L99 were loaded at a multiplicity of infection (MOI) level of 0.01. Cells were then incubated at $37^{\circ} \mathrm{C}$ for $2 \mathrm{~h}$. Cells were washed twice with pre-warmed serum-free DMEM and maintained in DMEM $(5 \mathrm{ml})$ supplemented with $2 \%(\mathrm{v} / \mathrm{v})$ FBS and incubated at $37^{\circ} \mathrm{C}$ for 8 days. Cell culture supernatants $(1.0 \mathrm{ml})$ were collected each day after the third day postinfection and an identical amount of fresh medium was added. Viral antigen levels were assayed by ELISA using the L13F3 mAb, as described above. Supernatant Hantaviruses titers were determined by serially diluting supernatants of each virus stock and performing quadruplicate infections on Vero-E6 cells in 96-well plates. The TCID50 assay endpoint was determined on day 10 . Used medium was discarded and cells fixed in $80 \%(\mathrm{v} / \mathrm{v})$ ice-cold acetone. Viral antigen were detected by horseradish peroxidase conjugated L13F3 monoclonal antibody, TMB peroxidase substrate (Dimethylformamide and hydrogen peroxide) was added to develop color. Absorbance at $450 \mathrm{~nm}$ (reference $620 \mathrm{~nm}$ ) was read with a DTX 880 multi-mode detector (Beckman Coulter). The cut-off value was determined by the 3 times SD above the mean absorbance of the negative control wells. And these were addressed at the part of methods. The TCID50 value was calculated by the method of Reed and Muench [18].

\subsection{Immunofluorescence assay (IFA)}

Specificity of the scFvs and intracellular distributions of $\mathrm{N}$ protein and intracellular scFvs were determined by indirect immunofluorescence assay (IFA). Hantavirusesinfected Vero E6 cells, stably transfected Vero E6 cells, or transiently transfected COS-7 cells were passaged onto sterile coverslips in six-well plates overnight. Cells were fixed by treatment with methanol for $10 \mathrm{~min}$ at $-20^{\circ} \mathrm{C}$ followed by acetone for $10 \mathrm{~min}$ at $-20^{\circ} \mathrm{C}$. To eliminate nonspecific binding, cells were pre-incubated with PBS containing 5\% (v/v) FCS for $30 \mathrm{~min}$ at RT in a humidity chamber. Antibody dilutions of 1:50 for H34 
IgG, 1:100 for L13F3 $\mathrm{mAb}, 5 \mu \mathrm{g} / \mathrm{ml}$ of purified anti-N protein scFvs, and 1:200 for anti-penta-His mAb in PBS containing 5\% FCS were used. The first round of incubation was carried out for $1 \mathrm{~h}$ at RT. For detection of bound, purified anti- $\mathrm{N}$ protein scFvs, the secondary antibody (mouse anti-His tag $\mathrm{mAb}$ ) was loaded and incubated for $1 \mathrm{~h}$. Antibodies were detected using either an antihuman fluorescein isothiocyanate (FITC)-conjugated secondary antibody or anti-mouse tetramethyl rhodamine isothiocyanate (TRITC)-conjugated antibody. Coverslips were washed in PBS, mounted on glass slides, and imaged under a TCS NT confocal microscope (Leica, Wetzlar, Germany).

\subsection{His tag pull-down assay}

About $5 \times 10^{7}$ HTNV-infected Vero E6 cells or the stably transfected cell lines L13F3-scFv-ER-E6, H34-scFvER-E6, L13F3-scFv-CYTO-E6, and H34-scFv-CYTO-E6 were harvested by centrifugation. Pellets were lysed in 1 $\mathrm{ml}$ ice-cold extraction buffer [TBS, pH 7.5; containing phenylmethylsulfonyl fluoride $(1 \mathrm{mM})$, aprotinin $(5 \mu \mathrm{g} /$ $\mathrm{ml})$, leupeptin $(5 \mu \mathrm{g} / \mathrm{ml})$, and $1 \%(\mathrm{v} / \mathrm{v})$ Triton X-100] and gently rotated for $30 \mathrm{~min}$. Samples were centrifuged at $4^{\circ} \mathrm{C}$ and $12,000 \mathrm{rpm}$ for $10 \mathrm{~min}$ to remove cell debris. Ni-NTA His-bind resin (200 $\mu \mathrm{l}$; Stratagene, La Jolla, CA, USA) was added and cleared supernatants were incubated at $4^{\circ} \mathrm{C}$ and $600 \mathrm{rpm}$ in an Eppendorf thermomixer for $2 \mathrm{~h}$. The resin was then harvested by centrifugation for $2 \mathrm{~min}$ at $4000 \times g$ at $4^{\circ} \mathrm{C}$ and washed five times with $1 \mathrm{ml}$ PBS and then five times with $1 \mathrm{ml}$ PBS containing imidazole $(20 \mathrm{mM})$. Bound proteins were eluted from the resin by incubation at $4{ }^{\circ} \mathrm{C}$ in $500 \mu \mathrm{l}$ PBS containing $500 \mathrm{mM}$ imidazole. Pull-down elutes were stored at $-80^{\circ}$ $\mathrm{C}$ in $100-\mu \mathrm{l}$ aliquots. Aliquots were concentrated by adding two volumes of ice-cold $100 \%$ ethanol and centrifuged at $10,000 \times g$ for $10 \mathrm{~min}$; pellets were resuspended in $10 \mu \mathrm{l} \mathrm{dH_{2 }}$ O followed by analysis by SDSPAGE and immunoblotting with anti-penta-HIS (Qiagen, Hilden, Germany) and L13F3 N protein-specific mAbs as described above.

\section{Results}

\subsection{Intracellular expression of L13F3, H34 scFvs}

To determine the binding activity of the recombinant scFvs, immunoblot and IFA and ELISA analyses on HTNV strain 76-118 and SEOV strain L99 were performed. Figure 1 depicts an immunoblot using L13F3 (Figure 1A, left panel) and H34 scFvs (Figure 1A, right panel) to probe viruses. The L13F3 scFv showed binding to both strain 76-118 and L99; this finding was corroborated by IFA data (Figure 1B, panel 1 and 2). The H34 scFvs bound only to HTNV strain 76-118 (Figure 1B, panel 3) and not SEOV stain L99 (Figure 1B, panel 4) in the IFA test, and no binding was detected by
A

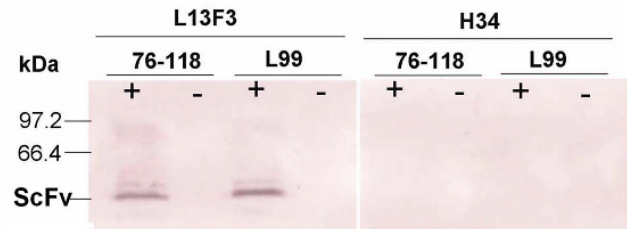

B
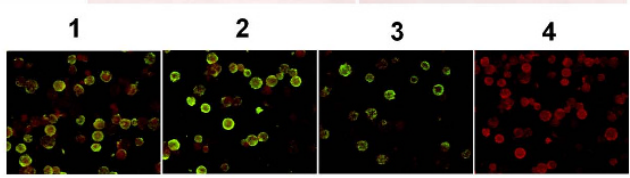

C

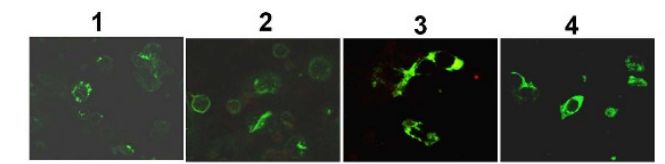

Figure 1 Characterization of recombinant scFv antibodies A) Immunoblot analysis of recombinant scFvs. Concentrated 76-118 and L99 virus were separated on 12\% SDS-PAGE and blotted on PVDF membrane, parallel treated normal vero E6 cells culture supernatant was used as negative control, the membrane was incubated with prokaryotic produced and purified scFv, and mouse anti- penta-His tag monoclonal antibody, detected with horseradish peroxidase-conjugated goat anti-mouse antibody. B)

Immunofluorescence analysis of recombinant scFvs, recombinant $\mathrm{N}$ protein expressing SF9 cells were fixed on dot slides, incubated with scFvs, (1) 76-118 N incubate with L13F scFv; (2) L99 N incubate with L13F scFv; (3) 76-118 N incubate with H34 scFv; (4) L99 N incubate with $\mathrm{H} 34 \mathrm{scFv}$. C) Intracellular localization of scFvs. COS-7 cells were seeded onto a 6-well plate, grown to $80 \%$ confluency, and transfected with intracellular antibodies expressing plasmid (1) L13F3-sCFv-CYTO; (2) H34-scFv-CYTO; (3) L13F3-SCFv-ER and (4) H34scFv-ER. The cells were fixed at $48 \mathrm{~h}$ posttransfection, and the scFvs was identified with IFA by using anti-His MAb, images were obtained with confocal microscope with $100 \times$ objectives.

immunoblotting (Figure 1A, right panel). These data are consistent with the binding activities of the L13F3 and H34 parent antibodies.

Intracellular localization of scFvs was determined by indirect immunofluorescence. As expected, L13F3 and H34 scFvs-Cyto accumulated in the cytoplasm of transfected cells (Figure 1C, 1 and 2), while L13F3 and H34 scFvs-ER yield a typical ER specific morphological fluorescence image (Figure 1C, 3 and 4).

\section{2. $\mathbf{N}$ protein interacted with intracellular antibodies in vivo}

To investigate whether $\mathrm{N}$ protein interacts with intracellular scFvs in vivo, a His-tag pull-down experiment was performed. To exclude any nonspecific binding to Hisbind resin, 76-118 or L99 virus-infected Vero-E6 cells were used as negative controls and normal Vero-E6 cells as blank controls. $\mathrm{N}$ protein and intracellular scFvs were detected by SDS-PAGE analysis of the pull-down eluates (Figure 2A, lanes 2, 4, and 6). However, scFv 


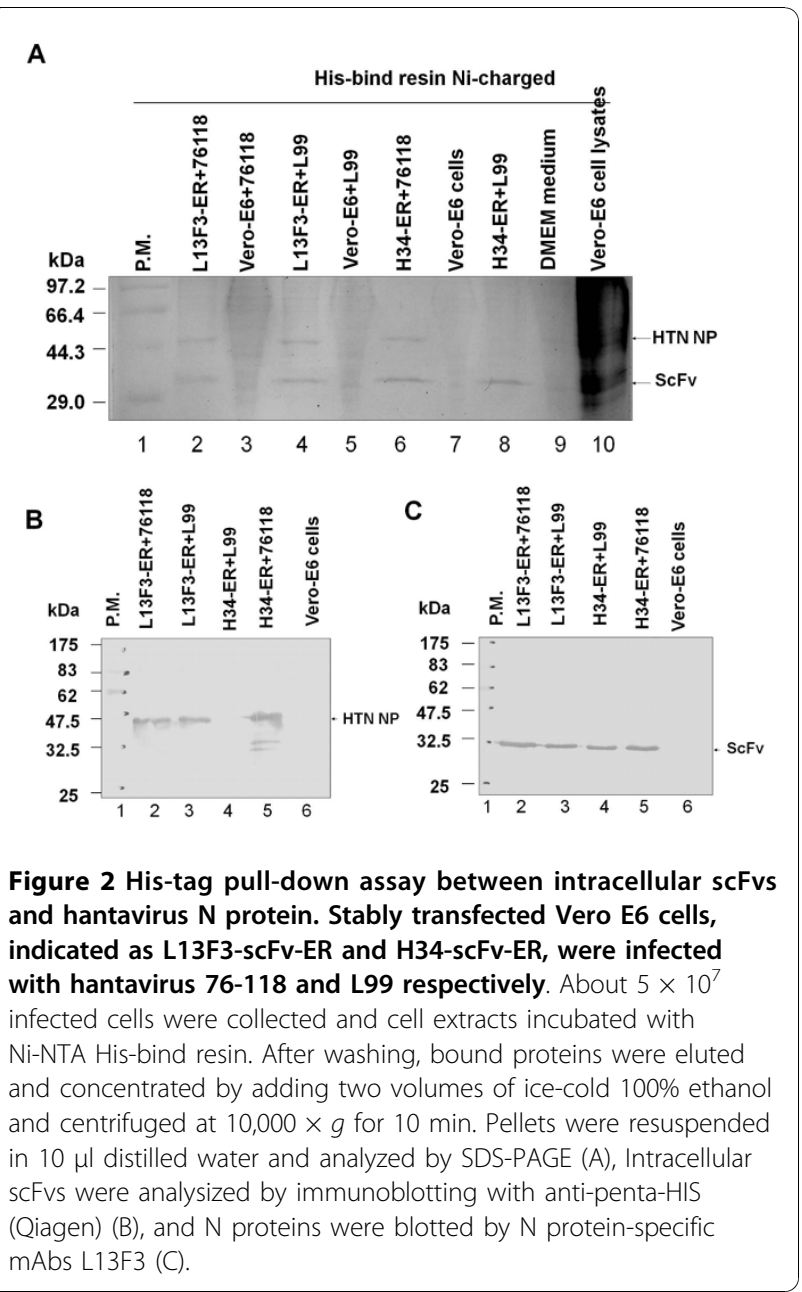

H34, which proved to be a HTNV type-specific antibody, did not pull-down the N protein of Seoul L99 virus, as expected (Figure $2 \mathrm{~A}$, lane 8 ). $\mathrm{N}$ protein and scFvs were not found in either negative or blank controls (Figure 2A, lanes 3 and 5). These observations were confirmed by detection with either anti-N protein $\mathrm{mAb}$ (Figure $2 \mathrm{~B}$ ) or anti-His $\mathrm{mAb}$ (Figure $2 \mathrm{C}$ ) in immunoblot assays. Therefore, $\mathrm{N}$ protein and the $\mathrm{N}$ proteinspecific scFvs likely specifically interact in vivo.

\subsection{Hantavirus $\mathbf{N}$ protein co-localized with intracellular antibodies}

Intracellular localization of $\mathrm{N}$ protein in transiently cotransfected COS-7 cells or virus infected Vero-E6 cells containing intracellular antibodies was determined under a confocal microscope. The recombinant $\mathrm{N}$ protein of HTNV strain 76-118 co-localized with intracellular L13F3 and H34 scFvs in both the ER and cytoplasm in COS-7 cells (Figure 3A). In contrast, the cytoplasmically expressed scFv did not co-localize with Gc protein of HTNV strain 76-118, but the ER-specific scFvs showed partial co-localization (Figure 3B). The N protein of HTNV strain 76-118 also co-localized with scFvs in Vero-E6 cell lines with L13F3-ER, L13F3-CYTO, H34-ER, and H34-CYTO antibodies, and L99 viral N protein co-localized only with L13F3 derived intracellular antibodies (Figure 3C).

\subsection{Inhibition of $\mathbf{N}$ protein trafficking reduced HTNV replication}

To determine the effect of intracellular antibodies on hantavirus replication, stably transfected L13F3-scFv-ERE6, H34-scFv-ER-E6, L13F3-scFv-Cyto-E6, and H34scFv-Cyto-E6 cell lines $\left(1 \times 10^{6}\right)$ were infected with HTNV strain 76-118 and SEOV strain L99 at a MOI of 0.01 . Cell culture supernatants were collected each day after the third day postinfection and viral antigen loads were determined by ELISA. Data suggested that HTNV $\mathrm{N}$ protein antigen levels in L13F3-scFv-ER-E6 and L13F3-scFv-Cyto-E6 cell lines were lower than that of control cells (Figure 4A). In contrast, $\mathrm{N}$ protein antigen levels in stably transfected H34-scFv-ER-E6 and H34scFv-Cyto-E6 cell lines decreased only when infected with HTNV strain 76-118, but not with SEOV strain L99 (Figure 4B). These data correlate with the antigen-binding specificities of the antibodies. No significant difference of virus replication was observed between stably transfected cell lines and normal non-transfected Vero E6 cells when intracellular antibodies were not specific for the infecting virus. This indicates that intracellular antibodies did not have a negative effect on cell growth, since the SEOV replication rate in H34 antibody-expressing cell lines was similar to that in control Vero E6 cells. HTNV levels in supernatants from the sixth day postinfection were titrated via TCID50 assay. Titers correlated with $\mathrm{N}$ protein antigen levels as determined by ELISA (Figure 5). These data indicate that both ER- and cytoplasm-targeted scFv antibodies inhibited HTNV replication. However, HTNV type-specific H34 antibody did not significantly affect replication of SEOV strain L99.

\section{Discussion}

In this study, we demonstrated that $\mathrm{N}$ protein of Hantaan and Seoul virus localizes to the ER/cis-Golgi in the absence of membrane glycoproteins. Data further suggested that $\mathrm{N}$ protein co-localized with intracellular antibodies with the ER retention marker SEKDEL. In addition, analysis of antibody-expressing cell lines, infected with viruses, revealed that $\mathrm{N}$ protein trafficking to the ER/cis-Golgi is important for viral replication. Blocking of $\mathrm{N}$ protein trafficking at both the ER/cis-Golgi and in the cytosol leads to inhibition of replication.

The $\mathrm{N}$ protein is a $420-430$ residue $50-\mathrm{kDa}$ protein, the N-terminal 75 residues of which carry two coiledcoil motifs that facilitate trimerization and nucleocapsid 


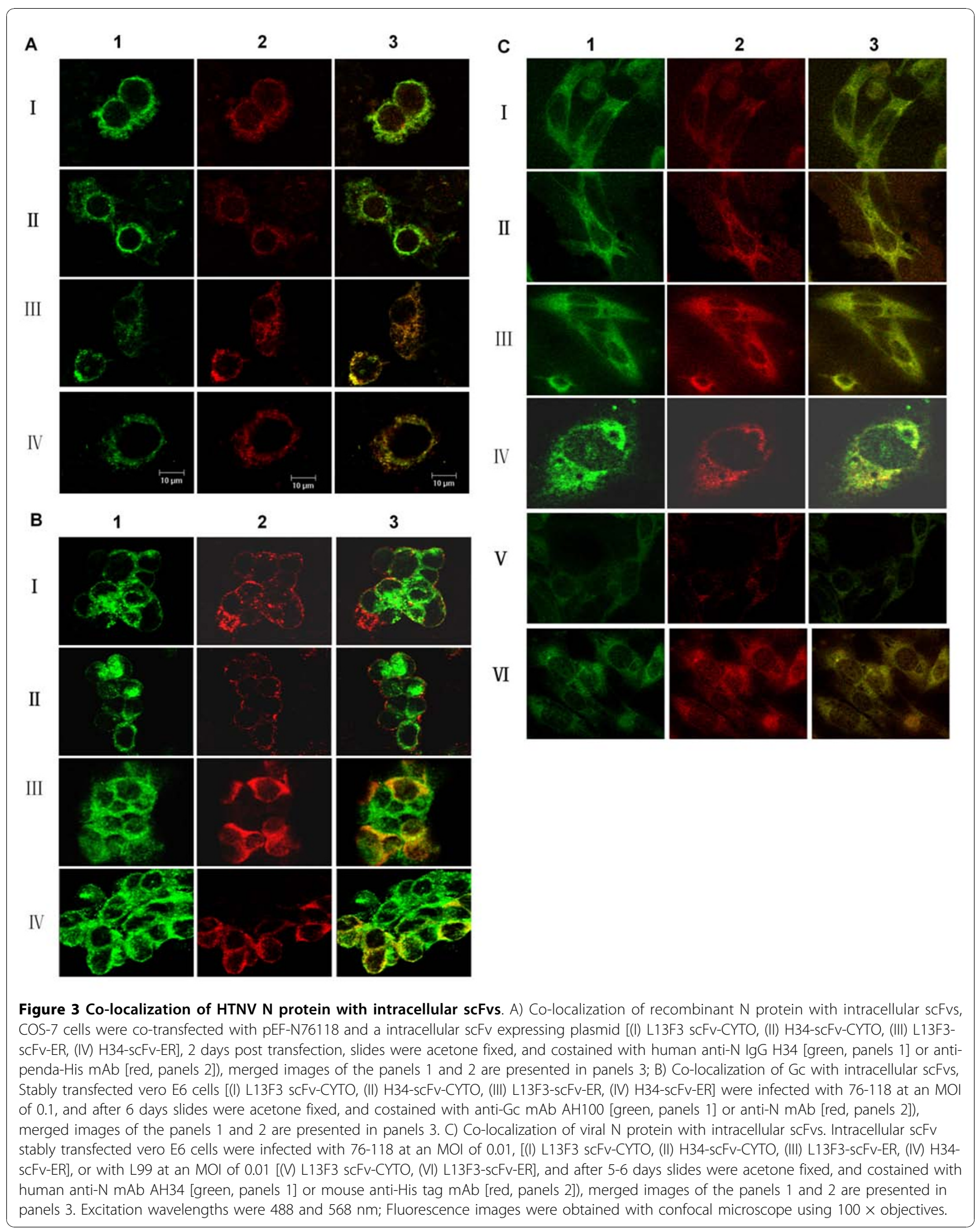




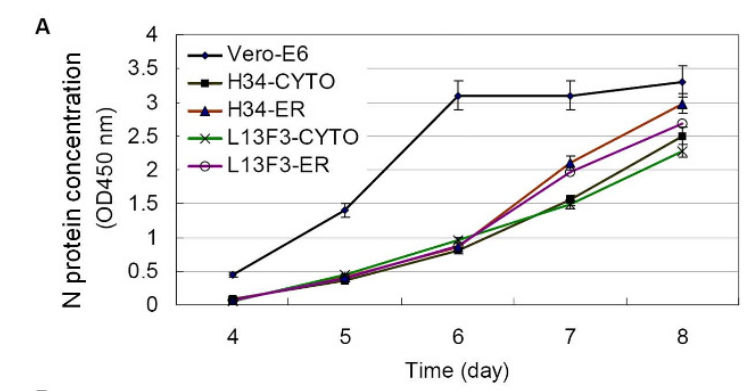

B

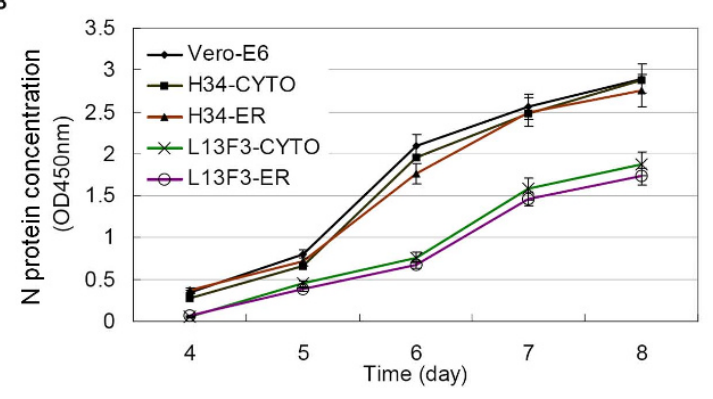

Figure 4 Hantavirus $\mathrm{N}$ protein levels in supernatants of virus infected cell lines determined by ELISA. (A) Infected with HTNV strain 76-118 and (B) infected with SEOV strain L99. Mouse anti-N mAb L13F3 was coated onto 96-well microtiter plates; detergenttreated culture supernatants were loaded and $\mathrm{N}$ protein was detected by horseradish peroxidase-conjugated anti-HTNV L13F3 mAb. Error bars represent the standard deviation of three independent experiments.

protein trimers that are believed to be HTNV particle assembly intermediates $[10,11]$. The L13F3 scFv antibody used in this study is known to bind to the $\mathrm{N}$ terminal 30 residues of $\mathrm{N}$ protein, which comprises part of

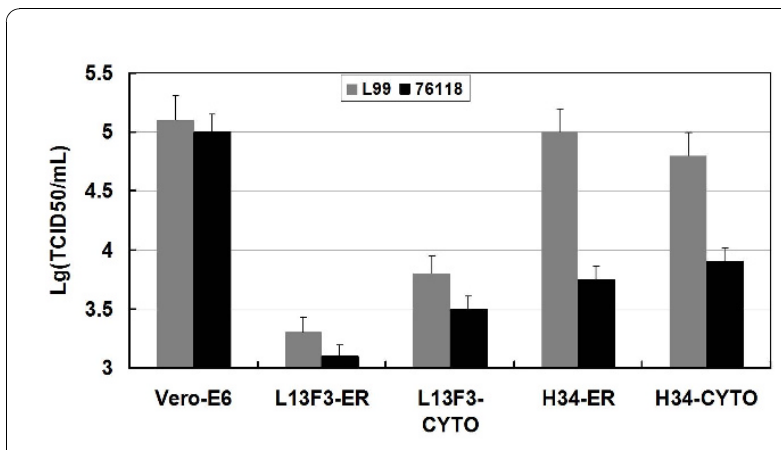

Figure 5 Titration of viral load in cell culture supernatants by TCID50 assay. Intracellular antibody-expressing stable cell lines were infected with hantavirus 76-118 and L99 respectively; virus titer at sixth day post infection was determined by the TCID50 assay. Endpoint was determined on day 10, cells fixed on the bottom of the culture plate by $80 \%(\mathrm{v} / \mathrm{v})$ ice-cold acetone. Viral antigen were detected by horseradish peroxidase conjugated L13F3 monoclonal antibody, virus infection was assessed by absorbance at $450 \mathrm{~nm}$ (reference $620 \mathrm{~nm}$ ). Error bars represent the standard deviation of three independent experiments. the first coiled-coil motif [11]. Additionally, H34 scFv has been shown to bind to a conformational epitope.

In hantaviruses, $\mathrm{N}$ protein is the first viral protein to accumulate during infection $[13,19,20]$. Viral RNA segments are complexed with $\mathrm{N}$ protein to form individual $\mathrm{L}, \mathrm{M}$, and $\mathrm{S}$ nucleocapsids [1], which are then packaged into the virion at the bilayered envelope within which are embedded the two viral surface glycoproteins $\mathrm{Gn}$ and Gc [21]. The specific interaction between $\mathrm{N}$ protein and glycoprotein is thought to trigger budding of virions into the Golgi cisternae and to initiate the virus assembly $[4,5]$. Although the laboratory evidences were presented recently, the precise mechanism of $\mathrm{N}$ protein entry into the ER/cis-Golgi apparatus remains unclear. ER-targeted scFvs used for tracking $\mathrm{N}$ protein intracellular trafficking were combined with a SEKDEL sequence at the carboxyl terminus. In mammalian cells, SEKDEL receptors are localized primarily to the early Golgi complex at steady state [22,23], but shift in their localization upon binding of SEKDEL-bearing ligands [24]. Therefore, we predicted that the ER-targeted scFvs would follow a route from the ER to the cis-Golgi and retrograde transport back to the ER. The co-localization and the proved interaction of $\mathrm{N}$ and ER-targeted intracellular antibodies indicate that $\mathrm{N}$ protein may entry into the $\mathrm{ER} /$ cis-Golgi apparatus. During virus infection, $\mathrm{N}$ protein or nucleocapsids also co-localized with ER-targeted antibodies. Virus replication was inhibited by the ERtargeted antibodies, which implies that $\mathrm{N}$ protein or nucleocapsids presented in membrane cisternae at the ER/cis-Golgi apparatus. Previous studies have shown that $\mathrm{N}$ protein is membrane-associated $[9,14]$, and that both targeting of $\mathrm{N}$ to ERGIC prior to its movement to the Golgi compartment and an intact ERGIC were required for viral replication [14]. In membrane subcellular fractionation experiments, a small proportion of total $\mathrm{N}$ protein was detected in membrane-containing fractions [14]. We hypothesize that $\mathrm{N}$ protein enters the ER or cis-Golgi apparatus, but only with low efficiency. An interaction between ER-targeted scFvs and membrane-associated $\mathrm{N}$ protein may act as a "motor" to enhance the entry of $\mathrm{N}$ protein into ER/cis-Golgi membrane vesicles. Like the function of the interaction of $\mathrm{N}$ protein and the cytoplasmic tail of $\mathrm{Gn} / \mathrm{Gc}$ during virus replication $[4,5]$. The ER provides a lower-energy environment than the Golgi system [25], which might enhance the entry of cytosol protein or nucleocapsids. The interaction between $\mathrm{N}$ and $\mathrm{G}$ protein is not the only prerequisite for the entry of $\mathrm{N}$ protein or cytosol nucleocapsids into membrane vesicles. Antibodies or other molecules might be alternative driver to direct the $\mathrm{N}$ protein to membrane vesicles. Immunoelectron microscopy examination of Uukuniemi virus, a bunyavirus, also demonstrated that the nucleocapsid is 
associated with membranes that show the characteristic distribution and tubulovesicular morphology of the preGolgi intermediate compartment, suggesting that the first site of formation of Uukuniemi virus particles is the pre-Golgi intermediate compartment and that virus budding continues in the Golgi stack [26].

In summary, the data we present in this study suggest that $\mathrm{N}$ protein may present in the ER/cis-Golgi without the assistance of viral $\mathrm{G}$ protein, and that $\mathrm{N}$ protein trafficking at these sites plays an important role in HTNV replication.

\section{Author details}

${ }^{1}$ State Key Laboratory for Infectious Disease Control and Prevention, Institute for Viral Disease Control and Prevention, China CDC, 155 Changbai Road, Changping District, Beijing 102206, PR China. ${ }^{2}$ State Key Laboratory Molecular Virology and Genetic Engineering, Institute for Viral Disease Control and Prevention, China CDC, 155 Changbai Road, Changing District, Beijing 102206, PR China.

\section{Authors' contributions}

LJ, ZQ and WT performed most of the experiments and involved in manuscript preparation. LC was involved in cells culture, virus infection and quantifications. LM participated in the design of the study and editing of the manuscript. LD participated in the design and the analysis of the data and editing of the manuscript. All authors read and approved the final manuscript.

\section{Competing interests}

The authors declare that they have no competing interests.

Received: 13 August 2010 Accepted: 24 November 2010 Published: 24 November 2010

\section{References}

1. Obijeski JF, Bishop DH, Palmer EL, Murphy FA: Segmented genome and nucleocapsid of La Crosse virus. J Virol 1976, 20:664-675.

2. Kaukinen $P$, Vaheri A, Plyusnin A: Hantavirus nucleocapsid protein: a multifunctional molecule with both housekeeping and ambassadorial duties. Archives of Virology 2005, V150:1693-1713.

3. Pedersen R, Melin L: Synthesis, assembly and intracellulat transport of Bunyaviridae membrane proteins. In The Bunyaviridae. Edited by: Elliott RM. New York: Plenum press; 1996:159-188.

4. Wang $\mathrm{H}$, Alminaite $\mathrm{A}$, Vaheri $\mathrm{A}$, Plyusnin $\mathrm{A}$ : Interaction between hantaviral nucleocapsid protein and the cytoplasmic tail of surface glycoprotein Gn. Virus Research 2010, 151:205-212.

5. Hepojoki J, Strandin T, Wang H, Vapalahti O, Vaheri A, Lankinen $H$ : Cytoplasmic tails of hantavirus glycoproteins interact with the nucleocapsid protein. J Gen Virol 2010, 91:2341-2350.

6. Mir MA, Panganiban AT: The bunyavirus nucleocapsid protein is an RNA chaperone: Possible roles in viral RNA panhandle formation and genome replication 10.1261/rna.2101906. RNA 2006, 12:272-282

7. Mir MA, Panganiban AT: Characterization of the RNA Chaperone Activity of Hantavirus Nucleocapsid Protein 10.1128/JVI.00147-06. J Virol 2006, 80:6276-6285.

8. Xu X, Severson W, Villegas N, Schmaljohn CS, Jonsson CB: The RNA Binding Domain of the Hantaan Virus N Protein Maps to a Central, Conserved Region 10.1128/JVI.76.7.3301-3308.2002. J Virol 2002, 76:3301-3308.

9. Ravkov EV, Compans RW: Hantavirus Nucleocapsid Protein Is Expressed as a Membrane-Associated Protein in the Perinuclear Region 10.1128/ JVI.75.4.1808-1815.2001. J Virol 2001, 75:1808-1815.

10. Alfadhli A, Love Z, Arvidson B, Seeds J, Willey J, Barklis E: Hantavirus Nucleocapsid Protein Oligomerization 10.1128/JVI.75.4.2019-2023.2001. J Virol 2001, 75:2019-2023.
11. Alfadhli A, Steel E, Finlay L, Bachinger HP, Barklis E: Hantavirus Nucleocapsid Protein Coiled-Coil Domains 10.1074/jbc.M203395200. J Biol Chem 2002, 277.27103-27108.

12. Kaukinen $P$, Vaheri A, Plyusnin A: Mapping of the Regions Involved in Homotypic Interactions of Tula Hantavirus N Protein 10.1128/ JVI.77.20.10910-10916.2003. J Virol 2003, 77:10910-10916.

13. Kariwa $\mathrm{H}$, Tanabe $\mathrm{H}$, Mizutani $\mathrm{T}$, Kon $\mathrm{Y}$, Lokugamage $\mathrm{K}$, Lokugamage $\mathrm{N}$, Iwasa MA, Hagiya T, Araki K, Yoshimatsu K, Arikawa J, Takashima I: Synthesis of Seoul virus RNA and structural proteins in cultured cells. Archives of Virology 2003, 148:1671-1685.

14. Ramanathan HN, Chung D-H, Plane SJ, Sztul E, Chu Y-k, Guttieri MC, McDowell M, Ali G, Jonsson CB: Dynein-Dependent Transport of the Hantaan Virus Nucleocapsid Protein to the Endoplasmic Reticulum-Golgi Intermediate Compartment 10.1128/JVI.00418-07. J Virol 2007, 81:8634-8647.

15. Bai $X$, Zhang $Y$, Wang $Y$, Pan $L$, Fack F, Bautz E: Fine mapping of epitopes of Hantaan virus nucleocapsid protein by peptides scanning. Journal of the Fourth Military Medical University 2000, 21:36-41.

16. Liang M, Duebel S, Li DL, Queitschb I, Li W, Bautz EKF: Baculovirus expression cassette vectors for rapid production of complete human IgG from phage display selected antibody fragments. Journal of Immunological Methods 2001, 247:119-130.

17. Gavrilovskaya IN, Brown EJ, Ginsberg MH, Mackow ER: Cellular Entry of Hantaviruses Which Cause Hemorrhagic Fever with Renal Syndrome Is Mediated by beta 3 Integrins. J Virol 1999, 73:3951-3959.

18. Reed LJ, Muench IL: A simple method for estimating fifty percent endpoints. American Journal of Hygiene 1938, 27:493-497.

19. Hutchinson KL, Peters CJ, Nichol ST: Sin Nombre Virus mRNA Synthesis. Virology 1996, 224:139-149.

20. Schmaljohn CS: Bunyaviridae and their replication. In Virology. Edited by: Fields BN, Knipe DM, Howley PM. Philadelphia: Lippincott-Raven pub; 1996:1447-1471.

21. Schmaljohn CS: Molecular biology of hantaviruses. In The Bunyaviridae. Edited by: Elliott RM. New York: Plenum Press; 1996:63-90.

22. Lewis MJ, Pelham HRB: A human homologue of the yeast HDEL receptor. 1990, 348:162-163.

23. Griffiths $G$, Ericsson M, Krijnse-Locker J, Nilsson T, Goud B, Soling H, Tang B, Wong S, Hong W: Localization of the Lys, Asp, Glu, Leu tetrapeptide receptor to the Golgi complex and the intermediate compartment in mammalian cells 10.1083/jcb.127.6.1557. J Cell Biol 1994, 127:1557-1574.

24. Lewis MJ, Pelham HRB: Ligand-induced redistribution of a human KDEL receptor from the Golgi complex to the endoplasmic reticulum. Cell 1992, 68:353-364.

25. Sciaky N, Presley J, Smith C, Zaal KJM, Cole N, Moreira JE, Terasaki M, Siggia E, Lippincott-Schwartz J: Golgi Tubule Traffic and the Effects of Brefeldin A Visualized in Living Cells 10.1083/jcb.139.5.1137. J Cell Biol 1997, 139:1137-1155.

26. Jantti J, Hilden P, Ronka H, Makiranta V, Keranen S, Kuismanen E: Immunocytochemical analysis of Uukuniemi virus budding compartments: role of the intermediate compartment and the Golgi stack in virus maturation. J Virol 1997, 71:1162-1172.

doi:10.1186/1743-422X-7-339

Cite this article as: Li et al:: Tracking hantavirus nucleocapsid protein using intracellular antibodies. Virology Journal 2010 7:339.

\section{Submit your next manuscript to BioMed Central and take full advantage of:}

- Convenient online submission

- Thorough peer review

- No space constraints or color figure charges

- Immediate publication on acceptance

- Inclusion in PubMed, CAS, Scopus and Google Scholar

- Research which is freely available for redistribution 